\title{
Role of Institutions in the Economic Development of Central and Eastern EU Countries
}

\author{
Mihai Talmaciu
}

Alexandru Ioan Cuza" University, Iasi, Romania

\begin{abstract}
Economic development of countries who experienced transition processes from autocratic regimes to democracy and the catching up of EU developed countries need to radical reform the institutional framework. The institutional quality can promote or inhibit development processes, especially in the countries that faced deep political, institutional and economic reforms and crises. This article intends to study the role and importance of institutions in the development process of Romania and other central and eastern EU countries and to identify the characteristics of the institutional framework exerting a stronger influence on the development. With this purpose we used data and information form different sources: World Bank statistics and reports, World Economic Forum Reports, reports of Legatum Institutes from London, scientific studies etc. We considered as useful the analysis of the nature and intensity of connection between institutional quality and the synthetic indicators of development. Romania and Bulgaria occupy the last two places in terms of development among the $27 \mathrm{EU}$ member states, but they also register the lowest values for institutional quality. The quality of the institutional framework is strongly dependent on aspects such as: property rights (including intellectual property), illegal payments and bribe, the independence of justice, the efficiency of the legal framework, the quality of political leadership, the capacity of economic and social actors to exert pressure to eliminate and change inadequate institutions, the quality of the connection between institutions and the organizations that are meant to supervise it.
\end{abstract}

Keywords: development, institutions, institutional quality, former socialist countries.

\section{Introduction}

The process of economic development is a very complex one due to the fact that the human beings (and society in its entirety), and their welfare are its primordial objective. Consequently, the complex and unpredictable nature, sometimes difficult to study and interpret, of the human behavior makes difficult the study of the factors lying at the bottom of development and defining some development models, universally valid and applicable on a wide scale in different countries, regions and localities.
The rich literature on the economic development mainly elaborated on the second half of the $20^{\text {th }}$ century, tries to identify the underlying factors of development, to explain their manner of action and finally build explanatory reasons of the development processes that might support the adoption of some policies and strategies adequate at national and/or regional level. The need to take into account some new explanatory variables for economic growth and development, was owed to the identification of a residual part of growth that may not be explained through

Copyright (c) 2012 Mihai Talmaciu. This is an open access article distributed under the Creative Commons Attribution License unported 3.0, which permits unrestricted use, distribution, and reproduction in any medium, provided that original work is properly cited. Contact author: Mihai Talmaciu E-mail: mtalm@uaic.ro 
the increase of work and capital volume used in economy, also known in the specialized literature as "Swan's residual value" (Baumol 2009, Rodriguez-Pose 2010). Thus, the followers of economic geography have brought into discussion the contribution of the territorial (regional, local) component and the endowment with production factors to the regional/local development process. The implication into the debate process of other specialists from the field of sociohuman sciences have brought into discussion the role of other variables in the stimulation and facilitation of the development process: culture and factors of cultural context, institution and institutional quality, environmental conditions, the political context, the evolution of economic structure etc.

To find an answer to questions such as "Why does development and growth rhythm accelerate/slow down in different periods and countries or regions?" or "Which are the causes of the existence and widening of disparities related to the development at world and/or national level?", the researchers of the phenomena of economic growth and development tried to identify new vectors that may contribute to the acceleration of development speed. Thus, besides the supporters of the neoclassic theory, researchers of the development phenomenon have come out who have approached a different view, underlining the important role of institutions in the stimulation and guaranteeing of proper compensation of initiatives and productive economic behaviours (North,1990).

Speaking again about institutions' role in the development process is owed to the followers of the new institutional economics whose main representative is Douglas North.. The authors following this type of approach have tried to underline the importance of institutional norms governing the rights of property (physical and intellectual), contracts and the limitation of investors' liability. Unfortunately, institutions have known a slow development and, generally, they cannot be copied and identically transplanted from a society (characterized by a certain economic, political, social and cultural context), where they operate correctly, into countries or regions in difficulty. To operate properly and prove their efficiency, institutions should develop locally, to result from the community's spirit and to have the support and involvement of their members.

The fact that institutions slowly develop and evolve induces obstacles and inconveniences both for the persons in charge with economic policies and economists due to the limited capacity to check their impact on development via empirical studies or conventional statistic analyses.

Between the neoclassic economists and the Keynesian ones, who have tried to work up to the solving of the "enigma" regarding economic growth, there is a generic consensus on the fact that institutional aspects (the capacity to manage an efficient system of institutional rights) and the absence of corruption, are essential for economic growth. Recognizing the important role of institutions in economic growth leads us to the idea that they have major implications on the development of human capital through the continuous improvement of manpower capacities.

\section{What are Institutions?}

Trying to define the concept of institution is a very complicated approach since the concept in itself is a controversial one, affected by subjectivism, and more difficult to operationalise in the study of economic development. The action of institutions on the development process is an indirect one as they may potentiate or prevent the action of other factors. Moreover, highlighting their influence may not be made by resorting to hard data supplied by the national or regional statistics but by resorting to qualitative data and information (soft data), the evaluation of impact being made on the basis of less precise attributes or criteria 
such as: adequacy level or favorability of institutions, solidity and stability, adaptability and dynamism, efficiency and effectiveness.

Contemporary sociologists use the term to refer to complex organisations/social forms such as governments, family, human languages, universities, hospitals, business organisations and legal systems. Jonathan Turner defined institutions as a complex of functions or situations, roles, norms and values, introduced in certain types of social structures, that determine relatively stable models of human behavior regarding the fundamental problems of production of the life essential resources and maintaining some viable social structures within a given environment" (Stanford encyclopaedia of Philosophy 2011, p.1). Anthony Giddens (1984) characterized institutions as durable features of social life.

Douglas North formulates a quite clear concise and accepted definition of institutions "which establish the rules of the game in a society, are human invented constraints influencing human interactions and modeling human behaviour" (North 1990). North frequently replaces the term institutions with that of constraints since they are in fact formal and/or informal rules forcing the economic and social actors to behave in a certain manner (Adriesse 2008).

The largest part of the specialized literature tends to group into two categories: formal institutions (laws, charters, statutes and regulations regarding the property rights, economic contracts, competition monitoring systems) and informal institutions represented by aspects resulted from the group life (norms or customs, traditions, agreements, social conventions, interpersonal contacts, informal relationships and networks). They tend to appear spontaneously following the repeated interactions within society and play an essential role in ensuring a high level of trust and social capital (North 1990, Fuhuyama
2000, Putnam 1998). Otherwise, Robert Putnam considers social capital as the most valuable "asset" for the generation of economic growth at regional/local level. Some components of informal institutions may acquire a formal character in time.

\section{Institutional Quality and Economic Development}

The influence of institutions on development has drawn the attention of researchers from the field of social sciences for more than a century (Rodrigues Pose 2006), but the trend to accentuate the role of institutional actors and regional and local policies in economic development intensified ever since the first half of the $9^{\text {th }}$ decade of the past century, especially in the developed industrialized countries.

In recent years, more and more economists affirm that institutions matter as much (if not more) in the process of economic development as traditional factors like the endowment with physical or human resources, market, technological transfer and know-how (Acemoglu et al. 2001, Vijayaraghavan and Ward 2001, Rodrik et al.2004, Andriesse 2008, Stimson et al. 2005).

If we accept the hypothesis that institutions have a determining role in the national or regional development processes, one must identify the types of institutions exerting an important influence on development and the manner of manifestation of influences. Some authors have oriented towards the study of influence of formal institutions and have identified the property rights and regulations as having the most important role (Rodrik et al. 2004, Acemoglu et al. 2001, Baumol et al. 2009). Others have oriented towards the study of the influence of some institutions with an informal character: trust (Knack 2003, Beugeldijk and van Schaik 2004, Bengtsson et al 2005) or social capital cooperation and collaboration (Putnam 1993, 2000, Beugeldijk and van Schaik 2005, Baumol et al. 2009). 
The presentation of some solid and efficient institutions at regional level is considered by some authors as a need and major requirement for the efficient functioning of markets in order to ensure development (Rodriguez-Pose 2010). Thus, institutions are considered as the basic element determining long-term economic performances (North 1990), and institutional quality is considered as a stronger advantage for the development of economies, than traditional factors (Rodrik et al. 2004).

The studies carried out have highlighted the various favorable effects of institutions on economies: they generate trust between the economic and social actors reducing transaction costs (North 1995, Fukuyama 2000), they supply public and collective goods (Streeck 1991), they promote the entrepreneurial spirit (Baumol 2009, Stimson et al.2005), they ensure the good functioning of labour market and correct market failures (Giddens 1990, Streeck 1991, North 1990, Rodriguez - Pose 2010, Andriesse 2008), they attenuate the effects of economic, social and political mutations (North 1990,1995), they contribute to the increase of economic efficiency (North 1995,
Streeck 1991, Andriesse 2008), they favor the implementation of development strategies and policies (Stimson et al. 2005, Streeck 1991, Andriesse 2008)).

Institutions may be adequate and efficient, in which case they favor the generation of positive economic effects, inadequate and inefficient by braking or preventing the activity of economic organisms through the reduction of information availability, increase of incertitude, making more difficult the different forms of effort coordination and the increase of transaction costs (Andriesse 2008, Nooteboom 2000). Douglas North distinguishes between institutions and organizations (political, social, economic, educational, health etc.) considering that interactions between the institutional framework and economic organizations have a special importance for economic development. Thus, institutional framework establishes the margins within which economic organisations may operate and may, in this way, either amplify the possibilities for economic development or limit or even reduce them (North 1990). Figure 1 shows the relationship between institutions and economic development. 


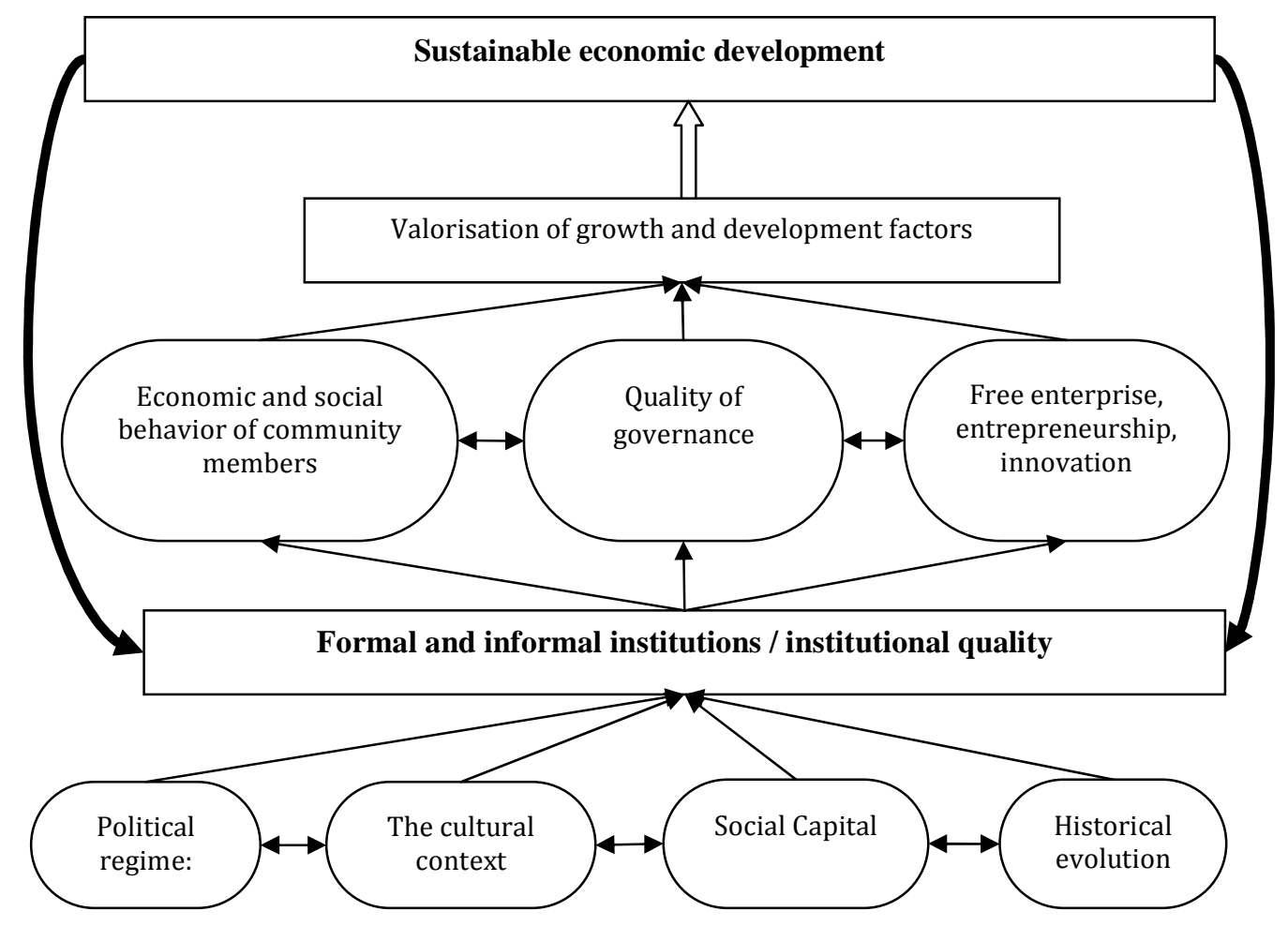

Figure 1: Relation between Institutions and Development

The presence of some adequate, solid and efficient institutions essential for a sustainable economic development. In the conditions of a weak institutional environment there is the risk of a strong control of elites over institutions what leads to "institutional sclerosis" that counteracts the opportunities for a sustainable development, determines non-satisfaction and mistrust in the decisional process regarding public policies and puts economic and social actors outside the development process. As Robert Putnam rightfully sustained, solid and efficient institutions are key factors favoring innovation, reciprocal learning and increase of productivity thus paving the way for delimitation and implementation of some efficient development strategies within territories and, finally, for economic growth. (Putnam 2000, p. 235).
Institutions manifest a certain resistance to change and interaction models from the institutional framework and economic organizations do not change for a short term, so a country, region or locality characterized by an inadequate and weak institutional framework may stay in a difficult situation for decades. The quite strong resistance of institutions to change may also be explained by the strong historical roots (North 1990, Andriesse 2008). Radical changes of the institutional framework take place only in case of events that may change the political regime. Even in such situations, the institutional framework existing in the former political regime may exercise negative influences on the new institutions because mentality and behaviour of the human factor are more difficult to change. 
To ensure a good quality of the institutional framework and efficiency of institutions' action, it is necessary to make a comprehensive approach of them, of the relationships between formal and informal institutions, the adoption of an integrated vision that may treat effects of institutions in tight connection with other aspects influencing the organizations' behaviour.

The evolution and continuous adaptation of institutions to conjunctural changes of economy as characteristics of institutional quality are dependent on the strong influence exercised by the political power on their nature (background) and form. Thus, inadequate institutions often persist due to the distribution of conflicts and the aggravation thereof in the context in which the economic, social and political actors, who should eliminate them, lack the necessary force and capacity (Bardhan 2005, Andriesse 2008).

The poor quality of the institutional framework leads to the exercise of a too strong control by the political and economic elites of institutions resulting in the accentuation of corruption which, at its turn, determines inefficacy of institutions' action, on the one hand, and the increase of mistrust of economic and social actors, on the other hand, transposing into a poor quality of governance at national or regional level. Scientific studies and international organisms show that only a high quality of governance may make a country or region pick the benefits of economic growth and development. The high quality governance contributes to the obtaining of a high level of human development ( Holmberg, Rothstein, Nasiritoussi 2009).

Measuring the institutional quality and implicitly governance quality is a difficult approach due to the comprehensive character of concepts what makes necessary the identification of some categories of concepts (indicators) in which they might be disaggregated. Such aspects that may be taken into account and assessed in order to measure governance quality are the adequacy level, efficiency and effectiveness, solidity, adaptability, coherence and clarity.

\section{Influence of Institutional Quality on the Economic Development of the Transitional Countries}

The process of economic development of the countries from the former socialist bloc from the central and south-eastern Europe was strongly marked by the fall of the communist regime and the transition processes towards democracy and the market economy. The transition from an autocratic regime towards democracy may be compared with the attempt to consolidate an old building from its foundation. If the architects who designed the process and the engineers who must implement it, intentionally or unintentionally, commit errors the existence of the building is jeopardized. Thus, transition imposed the complete reformation of such states, imposed a radical and complex process of political, economic, social and institutional reforms. The transition processes and institutional reforms had different characteristics from one country to another: they were longer or shorter, more coherent or lacked coherence, leaving their mark on the quality of institutions from the respective countries. The factors that influenced institutional quality in the countries from the former communist bloc are: quality, attitude and vision of political leadership in terms of the nature and characteristics of institutions, continuity and coherence of reforms at every change of the political power, the influence of some cultural characteristics such as social capital, the trust manifested by the society members, mentality and attitude towards the process of institutional restructuring, the influences exerted by the institutional framework of the former regime and the stronger or weaker inertia manifested by institutions in the reform process etc.

The most frequently used indicator to characterize the economic development of a country or region is GDP, but due to the 
7 Journal of Eastern Europe Research in Business \& Economics

complex character of the development process it is considered that it does not reflect correctly the development level. Consequently, they made attempts to create some synthetic indicators that might comprise the development level of a country in a single figure, from the angle of a large number of indicators. The data from table 1 show the development level of the 10 former socialist countries, which have recently acceded to the EU, from the perspective of several indicators.

Table 1: Indicators of Development of the Former Socialist Countries

\begin{tabular}{|c|c|c|c|c|c|c|c|c|c|c|}
\hline $\begin{array}{l}\text { Development } \\
\text { Indexes/Country }\end{array}$ & Bg & Ch & Est & $\mathrm{Hu}$ & Lat & Lth & Pl & Ro & Svk & Slo \\
\hline $\begin{array}{l}\text { Global } \\
\text { competitiveness } \\
\text { Index (GCI 2011) }\end{array}$ & 4,20 & 4,50 & 4,60 & 4,40 & 4,20 & 4,40 & 4,50 & 4,10 & 4,20 & 4,30 \\
\hline $\begin{array}{l}\text { Legatum Prosperity } \\
\text { Index (LPI 2010) }\end{array}$ & 0,06 & 1,33 & 0,77 & 0,78 & 0,05 & 0,32 & 1,14 & $-0,07$ & 0,67 & 1,64 \\
\hline $\begin{array}{l}\text { Human } \\
\text { Development } \\
\text { Index (HDI 2011) }\end{array}$ & 0,77 & 0,87 & 0,84 & 0,82 & 0,81 & 0,81 & 0,81 & 0,78 & 0,83 & 0,88 \\
\hline $\begin{array}{l}\text { Worlwide } \\
\text { Governance Index } \\
\text { (WGI) }\end{array}$ & 0,66 & 0,74 & 0,72 & 0,70 & 0,69 & 0,71 & 0,70 & 0,65 & 0,70 & 0,72 \\
\hline $\begin{array}{l}\text { Social capital } \\
\text { subindex - (LPI } \\
2010) \text { ) }\end{array}$ & $-0,72$ & 0,61 & 0,13 & $-0,76$ & $-1,57$ & $-0,39$ & 1,21 & $-2,48$ & 0,21 & 0,69 \\
\hline $\begin{array}{l}\text { Trust Others - (LPI } \\
\text { 2010) }\end{array}$ & 21,1 & 25,4 & 34,0 & 13,3 & 13,1 & 25,5 & 25,2 & 15,2 & 21,2 & 14,9 \\
\hline $\begin{array}{l}\text { GDP per capita PPP } \\
\text { (thou. US\$) } 2010\end{array}$ & 13,8 & 25,3 & 20,6 & 20,03 & 16,3 & 18,2 & 19,8 & 14,3 & 23,4 & 27,06 \\
\hline
\end{tabular}

Data processed by the author from the following sources: World Bank for GDP, LPI Report 2010, HDI Report 2011, GCI Report 2011

We may notice that there is a certain connection between the different ways of evaluation of a country's development level. Thus, the countries having the lowest performances in terms of GDP/inhabitant, Romania and Bulgaria, occupy the last two places in terms of synthetic indicators. Unlike Bulgaria, Romania has registered a worsening of the situation in the recent years having the lowest development level from the perspective of different indexes presented. At the same time, the countries registering the highest values of GDP/inhabitant such as Slovenia, the Check
Republic, Slovakia, Estonia, Hungary, Poland, have also registered much better performances from the perspective of aggregated indices.

We consider as useful the analysis of the connection between the values of such indicators, the type and intensity of this connection and the nature and intensity of the connection between institutions, social capital and trust and the synthetic indicators of development. For this purpose, we used Pearson's correlation coefficient whose values are given in table 2 . 
Table 2: Correlation Coefficients between Institutions and Indicators of Development of Former Socialist Countries

\begin{tabular}{|l|c|l|l|l|l|l|r|r|}
\hline Development Indexes & Inst. & GCI & LPI & HDI & WGI & CS & Trust & GDP \\
\hline Institutions & 1,00 & 0,71 & 0,35 & 0,36 & 0,52 & 0,37 & 0,54 & 0,26 \\
\hline GCI & & 1,00 & 0,58 & 0,45 & 0,76 & 0,67 & 0,72 & 0,43 \\
\hline LPI & & & 1,00 & 0,89 & 0,79 & 0,84 & 0,20 & 0,91 \\
\hline HDI & & & & 1,00 & 0,87 & 0,67 & 0,14 & 0,97 \\
\hline WGI & & & & & 1,00 & 0,74 & 0,44 & 0,85 \\
\hline Social capital subindex & & & & & & 1,00 & 0,52 & 0,74 \\
\hline Trust & & & & & & & 1,00 & 0,15 \\
\hline GDP & & & & & & & & 1,00 \\
\hline
\end{tabular}

Data source: calculation on data from table 1

As one may see in table 2, there is a direct connection, generally of a medium to low intensity, between the quality of institutions in the 10 countries under study and the development indicators. Even if there is not a strong connection, we may say that institutions exert an influence on the development of such countries by potentiating or inhibiting the action of other factors. The strongest connection may be noticed between institutions and GCI (0.71), a connection of medium intensity with population trust index, IGM and EPI and a lower intensity with social capital, HDI, LPI and SWL. We may also notice a direct and stronger correction between the values of the following indicators GDP, HDI, LPI and IGM suggesting that they supply close evaluations of the development level in the 10 countries. We must underline the quite strong connection between social capital and development indicators suggesting a significant influence of the social capital level on the economic development of the countries from the former socialist bloc. Taking into account the direct and strong connection between social capital and the development indicators and the fact that Romania is characterized by the lowest values of social capital and most of the development indicators, we may draw the conclusion that the poor development of some countries or regions may be explained by the weak collaboration and implication of the community members in the economic and social life.

In the case of Romania, institutional framework is characterized by a very low quality, the processes of institutional reform taking place very slowly and being characterized by a lack of coherence, each party that came into power trying to impose their own vision on the legal and institutional framework and to model it depending on their own interests. The low institutional quality determined the strong influence of political leadership and the strong control of political and economic elites on institutions, a fact that resulted in the accentuation of corruption, the inefficacy and inefficiency of institutions' action, the increase of mistrust into the economic and social actors and a poor quality and efficiency of governance.

To offer an image of quality of the institutional framework for the 10 states, we show the data from table 3 reflecting the institutional characteristics from the perspective of indicators used to estimate the value of the Institutions sub-index within Global Competitiveness Index. Each of the given indicators is evaluated on a scale from 1 to 7 . 
Table 3: The factors Relates on Institutional Quality in Former Socialist Countries

\begin{tabular}{|c|c|c|c|c|c|c|c|c|c|c|c|}
\hline & $\mathrm{Bu}$ & Ch & Est & Hu & Lat & Lth & Pl & Ro & Svk & Slo & $\begin{array}{l}\text { Pearso } \\
\text { n } \\
\text { coeff. } \\
\end{array}$ \\
\hline Property rights & 3,3 & 4,1 & 5,3 & 4,3 & 4,1 & 4,3 & 4,5 & 3,9 & 4,1 & 4,4 & 0,94 \\
\hline $\begin{array}{l}\text { Intellectual } \\
\text { property } \\
\text { protection }\end{array}$ & 2,9 & 3,7 & 4,8 & 4,1 & 3,6 & 3,5 & 3,7 & 3,0 & 3,8 & 4,2 & 0,82 \\
\hline $\begin{array}{l}\text { Diversion of public } \\
\text { funds }\end{array}$ & 2,9 & 2,3 & 4,8 & 2,6 & 3,3 & 3,0 & 4,1 & 2,8 & 2,5 & 3,4 & 0,89 \\
\hline $\begin{array}{l}\text { Public trust of } \\
\text { politicians }\end{array}$ & 2,3 & 1,7 & 3,9 & 1,8 & 2,4 & 2,0 & 2,5 & 1,9 & 1,7 & 2,3 & 0,86 \\
\hline $\begin{array}{l}\text { Irregular } \\
\text { payments and } \\
\text { bribes }\end{array}$ & 3,6 & 3,9 & 5,5 & 4,3 & 4,2 & 4,5 & 4,9 & 4,0 & 3,7 & 4,9 & 0,96 \\
\hline $\begin{array}{l}\text { Judicial } \\
\text { independence }\end{array}$ & 2,9 & 3,7 & 5,5 & 3,9 & 3,8 & 3,4 & 4,3 & 3,1 & 2,7 & 3,8 & 0,94 \\
\hline $\begin{array}{l}\text { Favoritism in } \\
\text { decisions of } \\
\text { government } \\
\text { officials }\end{array}$ & 2,5 & 2,4 & 4,0 & 2,8 & 2,9 & 3,2 & 3,3 & 2,5 & 2,1 & 2,7 & 0,91 \\
\hline $\begin{array}{l}\text { Wastefulness of } \\
\text { government } \\
\text { spending }\end{array}$ & 2,9 & 2,5 & 3,7 & 2,5 & 2,7 & 2,7 & 3,0 & 2,7 & 2,6 & 2,6 & 0,76 \\
\hline $\begin{array}{l}\text { Burden of } \\
\text { government } \\
\text { regulation }\end{array}$ & 3,1 & 2,6 & 4,3 & 2,3 & 3,3 & 2,8 & 2,6 & 2,8 & 2,7 & 3,0 & 0,68 \\
\hline $\begin{array}{l}\text { Efficiency of legal } \\
\text { framework in } \\
\text { settling disputes }\end{array}$ & 2,7 & 2,9 & 4,3 & 3,3 & 3,1 & 3,4 & 3,2 & 2,8 & 2,2 & 2,9 & 0,86 \\
\hline $\begin{array}{l}\text { Efficiency of legal } \\
\text { framework in } \\
\text { challenging regs }\end{array}$ & 2,8 & 2,9 & 4,3 & 2,8 & 3,0 & 3,7 & 3,3 & 2,9 & 2,4 & 3,0 & 0,85 \\
\hline $\begin{array}{l}\text { Transparency of } \\
\text { government } \\
\text { policymaking }\end{array}$ & 3,4 & 4,0 & 5,3 & 4,1 & 4,0 & 4,6 & 4,0 & 2,9 & 4,1 & 5,0 & 0,79 \\
\hline Organized crime & 3,9 & 5,5 & 6,6 & 5,4 & 5,5 & 5,7 & 5,7 & 4,9 & 4,7 & 5,8 & 0,89 \\
\hline $\begin{array}{l}\text { Reliability of police } \\
\text { services }\end{array}$ & 3,4 & 3,6 & 5,5 & 4,2 & 4,2 & 4,2 & 4,4 & 3,7 & 3,8 & 4,4 & 0,98 \\
\hline $\begin{array}{l}\text { Ethical behavior of } \\
\text { firms }\end{array}$ & 3,4 & 3,3 & 5,1 & 3,4 & 3,7 & 3,8 & 4,1 & 3,4 & 3,4 & 4,1 & 0,96 \\
\hline $\begin{array}{l}\text { Strength of } \\
\text { auditing and } \\
\text { reporting } \\
\text { standards } \\
\end{array}$ & 4,3 & 5,0 & 5,6 & 5,4 & 4,6 & 5,0 & 5,2 & 4,3 & 4,6 & 4,9 & 0,78 \\
\hline Institutions & 3,3 & 3,6 & 5,0 & 3,8 & 3,9 & 3,9 & 4,2 & 3,5 & 3,5 & 4,1 & 1,00 \\
\hline
\end{tabular}

Data processed by the author after The Global Competitiveness Report 2011 
From the data of table 3, we may draw the following conclusions:

- Most countries under analysis have registered low values of Institutions subindex, and the Global Competitiveness Index (World Economic Forum, 20112012 report) between 3.5 and 4.2;

- Romania and Bulgaria, the countries occupying the last two positions in terms of development level among the $27 \mathrm{EU}$ member states, are characterized by the lowest values of institutional quality, 3.5 and 3.3 , respectively.

- All countries under analysis are characterized by a poor institutional quality, a fact supporting the hypothesis that the process of instauration and evolution of the democratic institutions was strongly marked by the institutional framework specific to the autocratic regime.

- We may notice a direct and very strong connection (Pearson's coefficient over 0.9 or close to this value) between the institutional quality (value of Institutions aggregated sub-index) and some indicators such as property rights, illegal payments and bribe, independence of justice, favoritism in the decisions of the governmental officials, reliability of police services, ethical behaviour of companies, public fund misappropriation, public trust in politicians and the efficiency of the legal framework.

In the case of Romania, we may notice that the low level of institutional quality may be explained by poor performances registered for most indicators given in table 2, to which we may add the very low level of social capital and trust. Among the aspects related to the institutional framework exerting a strong negative influence on institutional quality and development we mention:

- The institution of property that registered a very slow evolution and lacked of coherence after 1990 (an example in this respect are the difficulties encountered in the implementation of the land reform in Romania, the ambiguities related to the reconstitution of the property right, the organization of the land market, the institution of lease, which have led to the decline of the agricultural sector and slow evolutions).

- The weak efficiency of the legal framework characterized by incoherence, instability and excessive complexity (twisted regulations giving rise to different interpretations and inhibiting or even preventing the initiatives of economic and social actors in the direction of development)

- The poor independence of justice that calls the existence and efficiency of democratic institutions in question;

- Burdening governmental regulations obstructing the free initiative and entrepreneurship and making Romania unattractive for foreign investors;

- The lack of transparency of governmental policies, which associated to favoritism in the adoption of decisions of governmental officials, leads to a high level of corruption, a too strong influence and implication of political elites into economy with deep negative effects on it. The poor quality of institutions is also determined by the fact that the officers of public institutions are often selected on the criterion of political allegiance or the allegiance to certain social groups, and the meritocratic criterion is too little taken into account.

In these conditions, the institutions, which have the role to establish the rules of the game in economy and society, prove to be inefficient in the implementation of development policies and strategies of Romania and they do not attain their objective to support and coordinate the efforts of the economic and social actors. 


\section{Conclusions}

The evaluation of quality of the institutional framework from a country or region and the influence thereof on the economic development is a difficult approach due to the complexity and unclear definition of concepts, the limited character of the available data and the use of subjective assessment criteria such as the adequacy level or favorability of institutions, solidity and stability, adaptability and dynamism, coherence and clarity, efficiency and effectiveness. Moreover, the characteristics of the institutional framework are dependent on factors such as the political regime and its stability, the historical evolution, the factors of the cultural context and social capital. The poor quality of the institutional framework leads to the control and strong influence of political and economic elites on institutions, the accentuation of corruption and a poor quality of governance and it jeopardizes democracy and the rule of law.

The development level of the 10 countries under study may be explained by the action of institutional factors that model the behaviour of economic and social actors and manifests a certain inertia and stability in time. The quality of institutional framework from such countries may contribute to the stimulation or inhibition of entrepreneurial initiatives and exerts an influence on the attractiveness of economies for investors. We may notice a direct connection of a moderate intensity between the quality of institutions and development indicators presented, what leads to the hypothesis of a certain influence of the institutional factors on development by potentiating or inhibiting the action of other factors. Most transitional countries are characterized by low levels of institutional quality justified by radical processes of institutional reform initiated after 1990 and the influence exercised by the institutional framework characteristic to the autocratic regime.

Romania and Bulgaria occupy the last two places in terms of development among the 27 EU member states, but they also register the lowest values for institutional quality. At the same time, we may notice a direct and strong connection between social capital and some development indicators, the low development level of some countries such as Romania and Bulgaria being explained by the insufficient social capital.

The quality of the institutional framework is strongly dependent on aspects such as: property rights and intellectual property, illegal payments and bribe, the independence of justice, favoritism in the decisions of the governmental officials, the reliability of police services, the ethical behaviour of companies, the public fund misappropriation, the public trust into politicians, and the efficiency of the legal framework. The quality of institutions is also marked by factors such as: the quality of political leadership, the capacity of economic and social actors to exert pressure so as to eliminate and change inadequate institutions, the quality of the connection between public, economic and social institutions and organizations that are meant to supervise the operation of institutions. A negative influence on the quality of institutional framework is exerted by a too strong influence (even control) by the political leadership on the activity of public organizations responsible for the implementation of institutional norms. Thus, the selection of public servants in Romania is made on criteria of political allegiance or allegiance to different influential groups and less on the meritocratic criterion.

\section{Acknowledgement}

This work was supported by the project "Post-Doctoral Studies in Economics: training program for elite researchers - SPODE" cofunded from the European Social Fund through the Development of Human Resources Operational Programme 20072013, contract no. POSDRU/89/1.5/S/61755.

\section{References}

Acemoglu, D., Johnson, S. \& Robinson, J. A. (2001). "The Colonial Origins of Comparative 
Development: An Empirical Investigation," American Economic Review 91(5), 13691401.

Adriesse, E. (2008). "Institutions and Regional Development in Southeast Asia," AD Druk - Zeist, Netherlands.

Bardhan, P. (2005). Scarcity, Conflicts and Cooperation, Essays in the Political and Institutional Economics of Development, Cambridge: MIT press.

Baumol, W. J., Litan, R. E., Schramm, C. J. \& Negro, N. (2009). Capitalismo Buono Capitalismo Cattivo: L'imprenditorialità e i suoi Nemici, Università Bocconi, Milano.

Bengtsson, M., Berggren, N. \& Jordahl, H. (2005). "Trust and Growth in the 1990s: A Robustness Analysis," Ratio Working Papers 60 , The Ratio Institute.

Beugelsdijk, S., de Groot, H. L. F. \& van Schaik, A. B. T. M. (2004). "Trust and Economic Growth," Oxford Economic Papers, 56: 118134.

Beugelsdijk, S. \& van Schaik, A. (2005). "Differences in Social Capital between 54 Western European Regions," Regional Studies, 39: 1053-1064.

Bosworth, B. P. \& Collins, S. M. (2003). "The Empirics of Growth: An Update," Brookings Papers on Economic Activity, 12.

Fukuyama, F. (2000). 'Social Capital and the Civil Society,' IMF Working Paper n. 74.

Giddens, A. (1990). 'The Consequences of Modernity: The Raymond Fred West memorial lectures,' Stanford University Press: Stanford, CT.

Holmberg, S., Rothstein B. \& Nasiritousi, N. (2009). "Quality of Government: What You Get," Annual Review of Political Science Vol. 12: $135-161$
Human Development Report 2011. Sustainability and Equity: A Better Future for All, United Nations Development Programme, [Online], [Retrieved January 20, 2012] http://hdr.undp.org/en/reports/global/hdr 2011.

Institutions for Regional Integration: Toward an Asian Economic Community, Asian Development Bank 2010.

Knack, S. (2003). "Groups, Growth and Trust: Cross-Country Evidence on the Olson and Putnam Hypotheses," Public Choice, 117(34): 341-55.

Knak, S. \& Keefer, P. (1997). "Does Social Capital have an Economic Pay-Off? A Cross Country Investigation," Quarterly Journal of Economics, 112.4:1251-1288.

North, D. C. (1990). Institutions, Institutional Change and Economic Performance, New York: Cambridge University Press.

North, D. C. (1995). The New Institutional Economics and Third World Development, London : Routledge.

Nooteboom, B. (2000). "Institutions and Forms of Co-Ordination in Innovation Systems," In: Organization Studies 21, pp. 915-939.

Putnam, R. D. (1993). 'Making Democracy Work: Civic Traditions in Modern Italy,' New Jersey: Princeton University Press.

Putnam, R. D. (2000). "Bowling Alone: The Collapse and Revival of American Community," New York: Simon and Schuster.

Rodríguez-Pose, A. (2010). “Do Institutions Matter for Regional Development?,” [Online], [Retrieved January 20, 2012], http://ideas.repec.org/p/imd/wpaper/wp20 10-02.html, 
Rodriguez-Pose, A. \& Storper, M. (2006). "Better Rules or Stronger Communities? On the Social Foundations of Institutional Change and Its Economic Effects," Economic Geography 82 (1): 1-25.

Rodrik, D., Subramanian, F. \& Trebbi, F. (2004). "Institutions Rule: The Primacy of Institutions Over Geography and Integration in Economic Development," Journal of Economic Growth, 9: 131-165.

Sala-I-Martin, X. (coord) (2011). The Global Competitiveness Report 2011- 2012, Professor Klaus Schwab World Economic Forum Editor, Centre for Global Competitiveness and Performance, [Online], [Retrieved February 15, 2012], http://www3.weforum.org/docs/WEF_GCR_ Report_2011-12.pdf

Scott, J. C. (1972). "Patron-Client Politics and Political Change in Southeast Asia," In: The American Political Science Review 66 (1), pp. 91-113.

Stanford encyclopaedia of Philosophy, Center for Study of language and Information, Stanford University, 2011, p.1.

Stimson, R. J., Stough Roger, R. \& Salazar, M. (2005). "Leadership and Institutional Factors in Endogenous Regional Economic Development," Investigaciones regionales, no. 7, Asociacion Espanola de Ciencia Regional, pp.23-52.

Streeck, W. (1991). 'On the Institutional Conditions of Diversified Quality Production,' In E. Matzner and W. Streeck (eds.) Beyond Keynesianism: Sociooeconomics of production and full employment. Aldershot: Edward Elger, pp. 21-61.

The 2010 Legatum Prosperity Index An Inquiry into Global Wealth and Wellbeing, Legatum Institute, London UK, [Online], [Retrieved February 10, 2012], http://www.prosperity.com.
Vijayaraghavan, M. \& Ward, W. A. (2001). 'Institutions and Economic Growth: Empirical Evidence from a Cross-National Analysis,' Working Paper Number 001302, Clemson, S.C.: Center for International Trade, Clemson University. 